\title{
WRFによるダウンスケーリングの不確実性が 貯水池水質予測計算に与える影響 \\ EFFECT OF UNCERTAINTIES IN DOWNSCALING RESULTS USING WRF MODEL ON WATER QUALITY PREDICTION IN A RESERVOIR
}

\author{
矢島 啓 1 崔 貞圭 $^{2} \cdot$ 谷口 健司 3 \\ Hiroshi YAJIMA, Jungkyu CHOI and Kenji TANIGUCHI \\ 1正会員 博 (工) 鳥取大学大学院准教授 社会基盤工学専攻（† 680-8552 鳥取市湖山町南4-101） \\ 西オーストラリア大学 Centre for Water Research 特上級研究員 \\ 2学生会員 修(工) 鳥取大学大学院 社会基盤工学専攻（† 680-8552 鳥取市湖山町南4-101） \\ 3 正会員 博 (工） 金沢大学特任助教 理工研究域環境デザイン学系（广920-1192 石川県金沢市角間町）
}

\begin{abstract}
In this research, we evaluated errors of meteorological data generated by a dynamical downscaling using a regional weather forecast model of WRF from JRA25 data along with several bias-correction technique applications. Then we investigated uncertainties of the water quality prediction in a reservoir due to those errors using a 3-D hydrodynamic and ecological model of ELCOM-CAEDYM. Comparisons of several bias-correction methods revealed that the quantile mapping method is most suitable. But a statistical downscaling was better for wind direction and wind speed correction might need very fine grid scale simulation to express wind field in a reservoir. In-reservoir water quality simulations revealed that errors of air temperature and solar radiation, which can be bias-corrected, were two major factors that affect the seasonal change of water temperature profile and the phytoplankton biomass in a reservoir.
\end{abstract}

Key Words : WRF, downscaling, water quality prediction, Quantile mapping, ELCOM-CAEDYM

\section{1.はじめに}

全球気候モデル (General Circulation Model; GCM) を用いた将来予測計算結果を用いて，気候変動が流 域水資源の量的変化に及ぼす影響を評価した多くの 研究がある ${ }^{1), 2)}$. 通常 GCMモデルの出力值は時間・ 空間解像度が荒いため, それらの研究には, 力学的 あるいは統計学的に解像度の高いデータへとダウン スケールされたデータが用いられている。しかしダ ウンスケールされたデータには, 系統的な誤差が含 まれているため, 何らかの手法でこの誤差を最小化 するための補正がなされる3),4),5). この補正手法の中 で最もよく用いられている手法が頻度分布マッピン グ(Quantile mapping)であり, Leungら ${ }^{6}$ は米国コロン ビア川流域における気候予測結果を補正するために 適用している。また, 補正されたデータにも誤差は 残っていると考えられるが，それらの值をもとに流 出計算などを行う場合には，そこで使用するモデル の精度に起因する予測結果の不確実性がさらに生じ る可能性がある7),8).

また近年においては，気候変動に伴う水資源の変 化の予測は，流域規模のものだけでなく，水資源と して重要な湖沼やダム貯水池の小スケールを対象と した研究に発展している9). しかしながら, 水質ま
で含んだ研究は生態系モデルとリンクした鉛直1次 元モデルによる評価が一般的であり ${ }^{10), 11)}$ ， 3次元湖 沼生態系モデルを用いた評価を行った例は少ない ${ }^{12)}$. しかし今後は，淡水水資源として重要な湖沼や貯水 池の水量・水質に気候変動が及ぼす影響を詳細に把 握する必要性が高まるものと考えられる．矢島ら ${ }^{13)}$ は，3次元水理-生態系モデルELCOM-CAEDYMを用 いて, 温暖化が植物プランクトンを含む水質に与え る影響評価を行っているが，温暖化予測とは直接リ ンクされていない感度分析にとじまっている。

このような状況から, 詳細な3次元湖沼生態系モ デルとGCMモデルおよびそのダウンスケールをリ ンクした研究が急務であると考えられる。しかし先 に述べたように，気候モデルを用いた将来気候によ る影響評価を詳細に行うためには，使用するモデル やダウンスケールに伴う不確実性が湖沼や貯水池で の水量・水質に与える影響を評価する必要がある。 そこで, 本研究ではGCMデータを用いる前段階の 検討として, 荒川水系の浦山ダムを対象に, 領域気 象モデルWRFを用いた力学的ダウンスケーリング を行い, その結果を複数の方法で補正したデータに ついて精度を評価するとともに, 貯水池生態系モデ ルを適応したときの, バイアス補正による不確実性 が貯水池水質に与える影響を評価する. 


\section{2. 研究方法}

\section{(1) 研究対象地域}

浦山ダムは，荒川水系上流部埼玉県秩父市（北緯 3557'12’”，東経139³'08'”）に位置し，秩父市・埼 玉県・東京都に合計日最大約 35 万 $\mathrm{m}^{3}$ の水道用水を 供給する首都圈にとって重要な水ガメである。 その 規模は，堤高 $156 \mathrm{~m} ，$ 堤頂長 $372 \mathrm{~m}$ ，集水面積 $51.6 \mathrm{~km}^{2}$, 湛水面積 $1.2 \mathrm{~km}^{2}$, 総貯水量 5,800 万 $\mathrm{m}^{3}$, 平常時最高 貯水位EL.393.3mの重力式コンクリートダムである. また, 洪水調節, 水道用水, 流水の正常な機能の維 持の供給および発電を行う多目的ダムである。

\section{（2）WRFを用いたカ学的ダウンスケーリング}

本研究では米国大気研究所を中心として開発され ている非静力領域気象モデルWeather Research Forecasting System（WRF）を用いて気候情報の力学 的ダウンスケーリングを行う。WRFの初期值及び 境界条件には気象庁と電力中央研究所のプロジェク トによる気象庁長期再解析データ (Japanese 25-year Reanalysis：JRA25）を用いる。JRA25はGMS再計 算衛星風，熱帯低気圧周辺風， SSM/Iによる可降水 量・積雪域情報，中国積雪データ等の使用により， 全球平均月別降水量や熱帯低気圧等の表現に秀でて いるとされる。WRFの実行に必要な海水分布, 海 陸分布, 標高, 土壤タイプ，植生タイプ等の陸面情 報に関しては米国環境予測センターによるNCEP FNLを用いる。また, 下部境界条件として必要な海 面水温にはNOAA Optimum Interpolation 1/4 Degree Daily Sea Surface Temperature Analysisを用いる.

本研究では解像度の異なる3つの領域をネスティン グすることにより，ダウンスケーリングを行う。モ デルの水平格子間隔は粗い方から $90 \mathrm{~km} ， 30 \mathrm{~km}$, $6 \mathrm{~km}$ とした。各領域がカバーする範囲を図-1に示す. 積分間隔は空間解像度の粗い領域から，それぞれ 360 秒，120秒，24秒である。また，ダウンスケーリ ングは各月毎に行い，スピンアップ期間として各月 に先立つ10日間を与えている。

\section{(3) 研究対象地域バイアス補正方法}

WRFを用いて水平格子間隔 $6 \mathrm{~km}$ で力学的ダウン スケーリングされた結果から, 浦山ダムに一番近い グリッド（北緯3557’32.4”，東経1393’3.6”， モデ ル標高 $551 \mathrm{~m}$ ）の值（以下，「計算值」と呼ぶ）を， 浦山ダムにおける観測值（雲量については熊谷と前 橋地点の平均值）用いてバイアス補正する（以下バ イアス補正された值を「補正值」と呼ぶ）。なお， バイアス補正方法については，以下の5つを検討す る.

a）線形回帰式による補正法 (Linear regressions) 観測值と計算值の線形回帰式より得られた傾きお よび切片の係数 $a, b$ を用いて, 次式により補正され る.

$$
x^{\prime}{ }_{d i}=a \times x_{d i}+b
$$

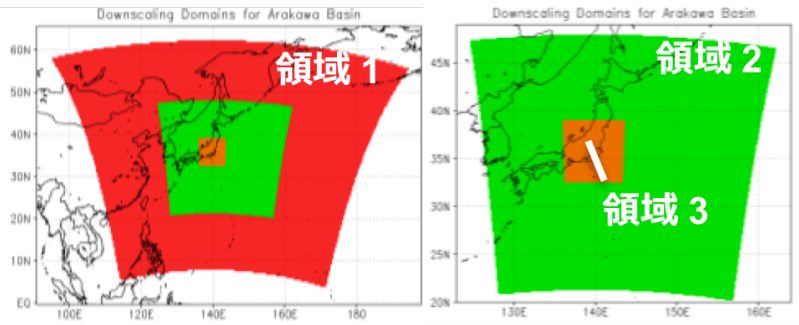

図-1 WRFによる計算領域. 空間解像度は領域1，2，3そ れぞれ $90 \mathrm{~km}, 30 \mathrm{~km}, 6 \mathrm{~km}$.

ここで $x_{d i}^{\prime}$ は補正された計算値， $x_{d i}$ は $i$ 番目の計算值 である。

b) 平均值の比による補正法（Relative ratios）

観測值と計算值の平均值の比を，すべての計算值 に脚け合わせることにより補正する.

$$
x_{d i}^{\prime}=x_{d i} \times \frac{\mu_{o b s}}{\mu_{d}}
$$

ここで $\mu_{o b s}$ は観測值の平均值， $\mu_{\mathrm{d}}$ は計算值の平均值 である。

\section{c）正規分布型バイアス補正法 (Parametric)}

観測值と計算值は同じ正規分布となるとし，それ ぞれの平均值と標準偏差が等しくなるように，頻度 確率をそろえる。

$$
x^{\prime}{ }_{d i}=\frac{\sigma_{o b s}}{\sigma_{d}}\left(x_{d i}-\mu_{d}\right)+\mu_{o b s}
$$

ここで $\sigma_{o b s}$ は観測值の標準偏差， $\sigma_{d}$ は計算值の標準 偏差である。

d) 頻度分布マッピング (Quantile mapping, hour Iy)

観測值と計算值それぞれの累積分布関数 (CDF) を 作成し，次式により計算值に対してマッピングを行 い補正する方法である。補正は計算期間すべての毎 時データを用いて処理する。

$$
x_{d i}^{\prime}=F_{o b s}^{-1}\left(F_{d}\left(x_{d i}\right)\right)
$$

ここで $F_{o b s}^{-1}$ は観測值の累積分布逆関数, $F_{d}$ は計算值 の累積分布関数である.

d') 頻度分布マッピング (Quantile mapping, seasonal)

d)で述べた方法から季節毎の変動パターンを考慮 するために4つの期間(春:3〜 5 月，夏: $6 \sim 8$ 月，秋:9 ～11月，冬:12〜2月)ごとにマッピングを行う.

\section{（4）バイアス補正に依らない気象データの補正}

貯水池水質予測計算に用いる気象データは，気 温, 湿度, 風速, 風向, 雲量, 日射量, 気圧の7項 目である。これらの項目のうち，風向は山間部に位 置するダム地形を反映した特性があるため，バイア スによる補正が困難であることが予想される。そこ で毎時の観測風向とダウンスケーリングから得られ た計算風向を16方位で分類し, 計算風向毎の最頻值 の風向である $22.5^{\circ}$ と $180^{\circ}$ の選択的に補正する統計 的な補正を行うこととした（図-2）. 


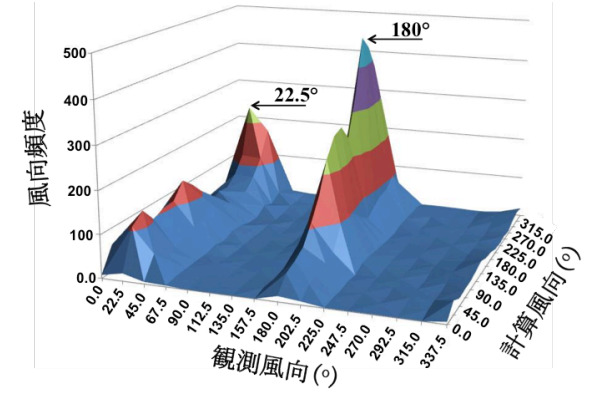

図-2 ダム地点における観測・計算風向の出現頻度

\section{(5) 貯水池モデルの構築}

浦山ダム貯水池における水質予測モデルは, 既存 研究 ${ }^{13)}$ で構築したモデルを使用し，年間降水量が平 年的であった 2000 年を対象に，4種類の植物プラン クトンに関するパラメータを中心に再キャリブレー ションを行う。また，浦山ダムに流入する 2 河川の 流量については観測值（流域面積による全流入量の 按分）を使用し，流入水質は既往のLQ式から設定 する.ただし，流入水温については，ダウンスケー リングの影響を取り込むため，気温から推定する. 水温は2006年〜2011年(2008年はデータ欠測により 除外)まで5年間の実測值を用い，24・48・72時間の 気温の移動平均值から得られる多重回帰式による推 定式式 (5) を作成した. 本回帰式で得られる推定值 と実測值の比較で, 高い決定係数 $\mathrm{R}^{2}: 0.915$ （絶対 平均誤差 $\mathrm{AME}: 1.35^{\circ} \mathrm{C} ， 2$ 乗平均平方根誤差 $\mathrm{RMSE}: 1.71^{\circ} \mathrm{C}$, 平均誤差 $\mathrm{ME}: 0.00^{\circ} \mathrm{C}$ ）が得られ，十 分精度があると考えられた。

$$
\begin{gathered}
T w_{\text {inf }}=0.5413 \times T a_{24 \mathrm{~h}}-0.4716 \times T a_{48 \mathrm{~h}} \\
+0.6267 \times T a_{72 \mathrm{~h}}+1.6102
\end{gathered}
$$

ここで， $T w_{i n f}$ は流入水温 $\left({ }^{\circ} \mathrm{C}\right), T a_{24 \mathrm{~h}}, T a_{48 \mathrm{~h}}, T a_{72 \mathrm{~h}}$ は
それぞれ気温の $24 \cdot 48 \cdot 72$ 時間の移動平均值 $\left({ }^{\circ} \mathrm{C}\right)$ である。

\section{3. 貯水池水質予測計算に用いる境界条件の 補正結果}

(1) ダウンスケーリング気象データの補正

毎時観測值と前章に示した5つの方法による補正 結果についての項目ごとの比較を表-1に示す．ただ し，方法1〜5は，先にあげた補正法のa)〜d) に対応 している。また参考に，方法 0 として観測值と計算 值を直接比較したものも示した.

\section{a）項目毎の補正精度}

表-1に示される $\mathrm{R}^{2}$ で判断すると, 気温, 気圧・日 射量, 雲量, 湿度, 風速, 風向の順に精度が高いこ とが分かる。この順番で，気温から雲量までは $\mathrm{R}^{2} か ゙$ 0.5 を超えており，相関があると判断されるが，風 速・風向では $\mathrm{R}^{2}$ が 0.1 以下となり，ほとんど相関が ない，従って，ダム貯水池における風向・風速のよ うに局地性が強い項目については， $6 \mathrm{~km}$ 格子程度の ダウンスケーリングでは補正を行っても十分表現す ることができない，特に風向の $\mathrm{R}^{2}$ が最小であり，先 に示した統計的な補正の方が，信頼性が高いことが 明らかである。

\section{b）補正方法毎の精度}

$\mathrm{R}^{2}$ で判断すると季節によるCDF特性を考慮した方 法5(Quantile mapping, seasonal)の精度が高いことが 多いことが分かる（表-1）。

一番 $\mathrm{R}^{2}$ が高く，水質予測に大きな影響を及ぼす気 温に対するAMEとRSMEをみると，方法5の值が一


と，AMEとRMSEでは方法1 (Linear regressions)が最

\begin{tabular}{|c|c|c|c|c|c|c|c|c|}
\hline \multicolumn{2}{|c|}{$\begin{array}{c}\text { (項目毎に精度の高い值 } \\
\text { を赤字で表示) }\end{array}$} & $\begin{array}{l}\text { 気温 } \\
\left({ }^{\circ} \mathrm{C}\right)\end{array}$ & $\begin{array}{c}\text { 湿度 } \\
\left(10^{-2} \%\right)\end{array}$ & $\begin{array}{l}\text { 風速 } \\
(\mathrm{m} / \mathrm{s})\end{array}$ & $\begin{array}{l}\text { 風向 } \\
\left({ }^{\circ}\right)\end{array}$ & $\begin{array}{l}\text { 雲量 } \\
(0-1)\end{array}$ & $\begin{array}{l}\text { 日射量 } \\
\left(\mathrm{W} / \mathrm{m}^{2}\right)\end{array}$ & $\begin{array}{l}\text { 気圧 } \\
(\mathrm{hPa})\end{array}$ \\
\hline 方法 0 & \multirow{6}{*}{$\begin{array}{c}\mathbf{R}^{2} \\
\text { (無単位) }\end{array}$} & \multirow{5}{*}{0.865} & \multirow{4}{*}{0.380} & \multirow{4}{*}{0.088} & \multirow{4}{*}{0.002} & \multirow{5}{*}{0.502} & \multirow{4}{*}{0.600} & \multirow{5}{*}{0.610} \\
\hline 方法 1 & & & & & & & & \\
\hline 方法 2 & & & & & & & & \\
\hline 方法 3 & & & & & & & & \\
\hline 方法 4 & & & 0.382 & 0.085 & 0.001 & & 0.592 & \\
\hline 方法 5 & & 0.879 & 0.454 & 0.083 & 0.003 & 0.486 & 0.610 & 0.599 \\
\hline 方法 0 & \multirow{6}{*}{ AME } & 2.613 & 0.160 & 2.103 & 111.54 & 0.197 & 105.06 & 13.20 \\
\hline 方法 1 & & 2.441 & 0.141 & 1.409 & 80.14 & 0.210 & 82.67 & 2.924 \\
\hline 方法 2 & & 2.449 & 0.156 & 1.946 & 82.08 & 0.202 & 77.32 & 3.222 \\
\hline 方法 3 & & 2.487 & 0.151 & 1.807 & 96.53 & 0.218 & 91.33 & 3.061 \\
\hline 方法 4 & & 2.487 & 0.151 & 1.822 & 92.48 & 0.218 & 78.12 & 3.061 \\
\hline 方法 5 & & 2.328 & 0.139 & 1.843 & 92.41 & 0.218 & 75.39 & 3.102 \\
\hline 方法 0 & \multirow{6}{*}{ RMSE } & 3.479 & 0.205 & 2.919 & 140.47 & 0.282 & 200.52 & 13.85 \\
\hline 方法 1 & & 3.205 & 0.175 & 1.983 & 90.82 & 0.281 & 141.31 & 4.000 \\
\hline 方法 2 & & 3.218 & 0.201 & 2.657 & 106.97 & 0.282 & 142.35 & 4.434 \\
\hline 方法 3 & & 3.262 & 0.195 & 2.464 & 125.51 & 0.304 & 150.03 & 4.235 \\
\hline 方法 4 & & 3.262 & 0.195 & 2.460 & 120.94 & 0.304 & 148.23 & 4.235 \\
\hline 方法 5 & & 3.089 & 0.180 & 2.473 & 119.50 & 0.310 & 144.02 & 4.302 \\
\hline
\end{tabular}

表-1 5つの補正法による各項目の補正值と観測值の比較統計量 
も良い結果であるが，2000年の平均気圧が $965.8 \mathrm{hPa}$ であることを考慮すると，方法2～5においても大き な違いはない。また，気圧とほぼ同じR2であった日 射量をみると, 方法 5 あるいは方法 1(Linear regressions)の誤差が小さい. その他の項目について も，方法1あるいは方法5の精度が高い結果となった。 しかし, 方法1を将来予測時に適応寸る場合, 線形 補正は, 過大評価や過小評価を行う可能性があるた め, 方法5が一番安定した補正結果となると考えら れる. 風向については統計的補正を行うためここで は評価しないが，風速については，いずれの方法で も精度は低いため, 今後はさらに詳細なダウンス ケーリングを行うなどの検討が必要である.

\section{（2）流入水温の計算結果}

気温の補正誤差はそのまま流入水温の誤差につな がる。 そこで，ダウンスケーリングで得られた気温 の計算值と気温に対する補正法で一番精度の高かっ た方法5で補正された補正值を用いて，式(5)により 推定された水温と実測值を比較検討する.

実測值，計算值，補正值の毎時流入水温の年平均 值および変動範囲は, それぞれ $11.30{ }^{\circ} \mathrm{C}(0.6$ $\left.25.6{ }^{\circ} \mathrm{C}\right), \quad 11.25^{\circ} \mathrm{C}\left(0.9 \sim 20.0{ }^{\circ} \mathrm{C}\right), \quad 10.34{ }^{\circ} \mathrm{C}(0.1 \sim$ $\left.19.9^{\circ} \mathrm{C}\right)$ であった。このように気温を用いた算定で

\section{表-2 季節毎の平均水温（気温）}

\begin{tabular}{c|c|c|c|c}
\hline \multirow{2}{*}{ 単位 ${ }^{\circ} \mathrm{C}$} & $\begin{array}{c}\text { 春 } \\
\text { 3-5月 }\end{array}$ & $\begin{array}{c}\text { 夏 } \\
\text { 6-8月 }\end{array}$ & $\begin{array}{c}\text { 秋 } \\
\text { 9-11月 }\end{array}$ & $\begin{array}{c}\text { 冬 } \\
\text { 12-2月 }\end{array}$ \\
\hline \hline \multirow{2}{*}{ 実測值 } & 9.94 & 17.01 & 13.31 & 4.90 \\
& $(10.18)$ & $(22.41)$ & $(14.64)$ & $(2.85)$ \\
\hline \multirow{2}{*}{ 計算値 } & 10.35 & 17.66 & 12.28 & 4.65 \\
& $(12.35)$ & $(23.01)$ & $(15.48)$ & $(4.49)$ \\
\hline \multirow{2}{*}{ 補正值 } & 8.84 & 17.24 & 11.68 & 3.53 \\
& $(10.18)$ & $(22.41)$ & $(14.64)$ & $(2.85)$ \\
\hline
\end{tabular}

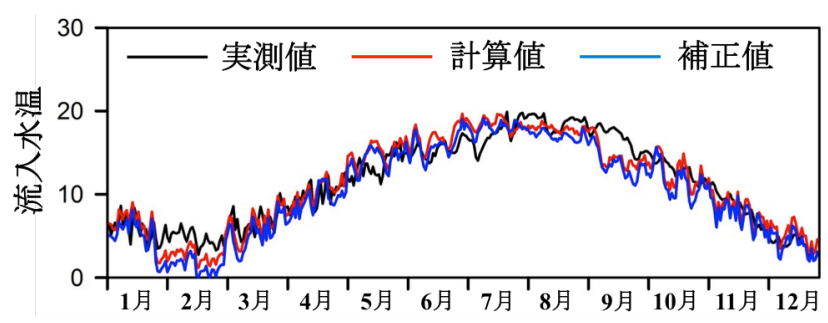

図-3 日平均流入水温の実測值・計算值 ·補正值の比較
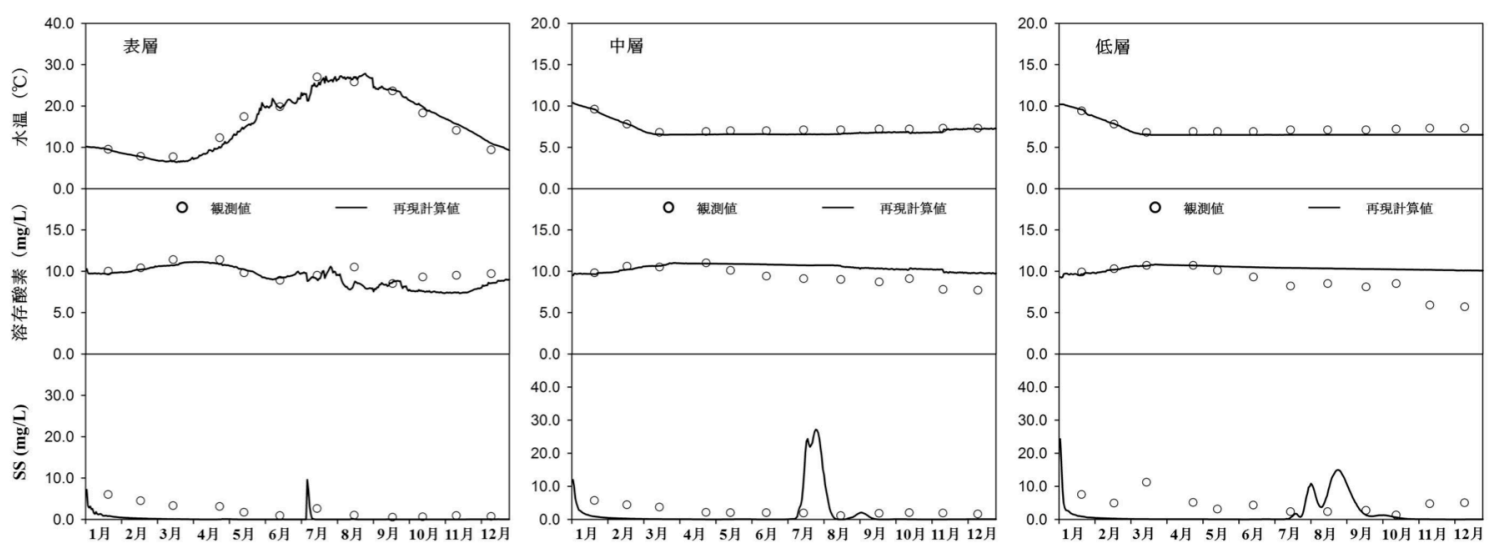

図-4 基準点での観測値と再現計算の比較結果1 (左:表層, 中: 中層, 右:底層; 上:水温, 中:溶存酸素, 下: SS)
は, 平均的な水温の推定はできても, 夏季日中の水 温上昇を過小評価している。 また，季節的な傾向を みると, 実測值に比べて, 計算値と補正值は冬と秋 に低く，夏に高い傾向がある。これらは，推定式の 特性と考えられた（表-2, 図-3）。

さらに気温データと併せて比較すると, 気温の補 正值と実測值は等しく, 計算値は実測值よりも高い 值を示している。しかし水温では, 計算值の方が実 測値に近いことが分かる（表-2）。これは，計算対 象とした 2000 年がダム供用開始の翌年であり，作成 した式 (5)の関係が流域状況の変化等の影響で近年 と異なっていた可能性がある.

\section{4. ダウンスケール計算結果が貯水池水質予 測結果に与える影響}

\section{（1）水質予測モデルの再現計算}

2000年を対象に, 水温と水質に対する再現計算を 行なった結果を, 貯水池内の基準点における定期調 查時の水温, 溶存酸素(DO), 濁度(SS), Chl.a, TN, $\mathrm{TP}$ の項目について, 表層 (水深 $0.5 \mathrm{~m}$ ), 中層 (平均 EL.332.5m), 低層 (平均EL.291.4m)の3か所で比較を 行った.

\section{a）水温の再現精度}

水温は表層, 中層, 低層での $\mathrm{R}^{2}$ はそれぞれ 0.961 , $0.968,0.933$ であり，AMEは $1.131 ， 0.313,0.470^{\circ} \mathrm{C}$ と RMSEは $1.336,0.356,0.522^{\circ} \mathrm{C}$ と十分な精度で再現計 算が行われた(図-4).

\section{b）水質の再現精度}

$\mathrm{DO}: \mathrm{R}^{2}$ は3つの層で $0.460,0.190,0.135$ とAME及 びRMSEは $0.821 ， 1.128,1.563 \mathrm{mg} / \mathrm{L}$ と $1.064 ， 1.366$, $2.149 \mathrm{mg} / \mathrm{L}$ であった。特に，10月以降のDO低下の 表現ができず，低層での計算誤差が大きくなった． また，この原因については，よく分からなかった (図-4).

SS : 図-4に示寸 $1 \sim 4$ 月にかけて前年から残留し ていた微細粒子と考えられるSS濃度の再現はでき なかったが，小規模の出水が1回あったが，洪水に 伴うSSの沈降は，ある程度再現できていた。

Chl.a : 濃度が高く一番問題となる表層の時系列 変化をよく再現できた。図は示していないが，植物 

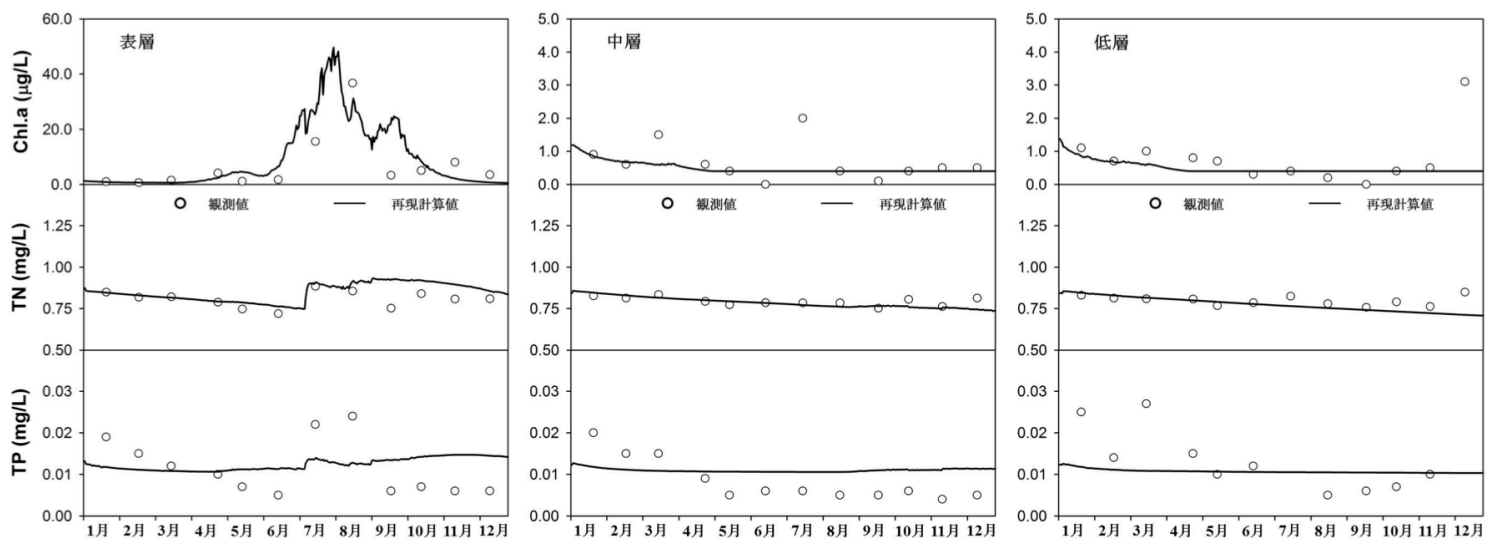

図-5 基準点での観測值と再現計算の比較結果2(左:表層, 中:中層, 右:底層；上:Chl.a, 中:TN, 下：TP)
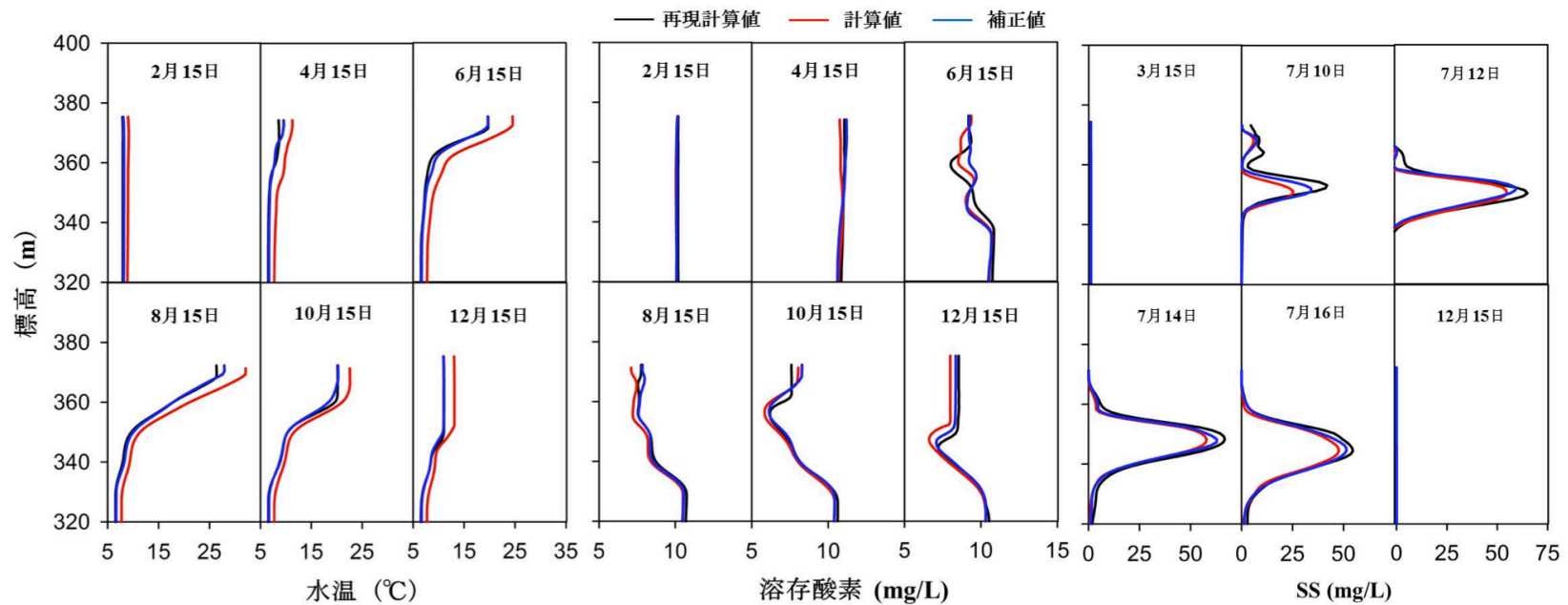

図-6 気象条件の補正の違いによる貯水池内基準点における水質変化 (左:水温，中：溶存酸素，右：SS)

プランクトン種毎の再現精度も良好であった(図-5)。

$\mathrm{TN}$ TP：TNはどの層においても再現精度が高 かった。これに対し， TPの3か所での $\mathrm{R}^{2}$ は 0.030 , $0.078,0.001$ と精度が低かった。流入河川の $\mathrm{TP}\left(\mathrm{PO}_{4}\right.$ $\mathrm{P})$ のLQ式による推定誤差，植物プランクトンやSS に関するモデルパラメータに起因する問題があると 考えられた (図-5).

\section{（2）ダウンスケーリング気象データが貯水池水質予}

\section{測結果に与える影響}

ダウンスケーリングから得られた直接の值をもと に水質予測計算を行ったケース（計算值）と流入水 温と同様にダウンスケーリングからの值を方法 5

(Quantile mapping, seasonal) によって補正（風向 は統計学的補正）した值をもとにした水質予測計算 を行ったケース（補正值）の2ケースを，再現計算 結果のケースと比較し考察する。

\section{a）水温分布に与える影響}

浦山ダムの基準点での再現計算值と補正值の水温 分布はほぼ同じあったが，計算値はそれらより明ら かに高い水温となった（図-6）。6月21日の表層に おいて，計算值は補正值よりも $6.3^{\circ} \mathrm{C}$ 高い水温で あった (最大較差) 。これは入力された気象データ で，観測值の年平均気温は $12.54{ }^{\circ} \mathrm{C}$, 計算值は $13.85^{\circ} \mathrm{C}$, 補正值は $12.54^{\circ} \mathrm{C}$, 年平均日射量はそれぞ
れ 130.2, 207.2, $141.0 \mathrm{~W} / \mathrm{m}^{2}$ と, 計算值が観測值と 補正值より気温，日射量ともに大きな值をとってい るとともに，計算で得られた気温を外力の境界条件 として与えているため，計算值においては不自然な 熱収支が生じている場合があるためである。

\section{b）DO分布に与える影響}

DO分布は，水温分布ほよ゙大きな違いはみられず, 12月 15 日の分布で分かるように，水温の違いによる 飽和濃度の違いが原因の差が支配的である（図-6 中）。ただし，6〜8月の分布でこれが明確でないの は，植物プランクトンの光合成の影響を受けている からと考えられる（図-7上）。

\section{c）SS分布に与える影響}

$\mathrm{SS}$ の場合，3つのケースで大きな違いは見られな かった（図-6右）。これは，計算值での水温分布は 他のケースよりも温かいものの，流入水温も同様に 高くなるため，濁水の貫入状況に違いが見られな かったからと考えられる.ただし将来は, 流出モデ ルと組みわせて流入量を変化させるときには，雨 量・流量の誤差が大きく影響を及ぼすと推測できる. d）表層Chl.alこえる影響

貯水池内基準点の表層におけるChl.aの違いは明 らかであった。 日平均最大Chl.aで再現計算值，計 算值，補正值はそれぞれ49.7(8月2日)，60.6(7月 15 


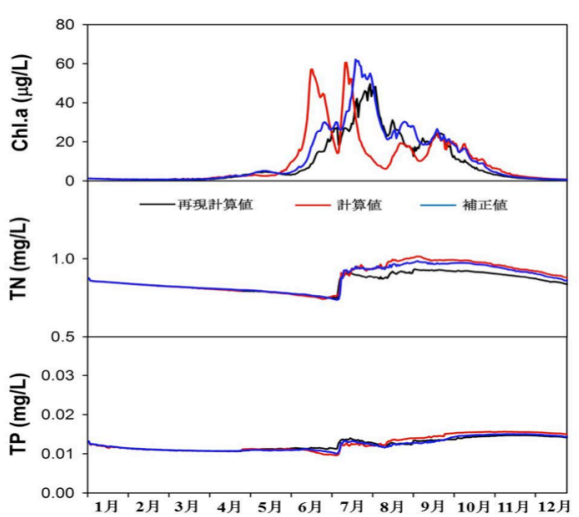

図-7 ダウンスケーリングから得られた気象条件の補 正による貯水池内基準点表層における日平均の 水質変化 (上:ChI. a, 中:TN, 下:TP)

日), $62.1(7$ 月 22 日) $\mu \mathrm{g} / \mathrm{L}$ と, 最大濃度とその発生日 も異なった（図-7上）。特に計算值においては，水 温が高くなった影響を受けて, Chl.aのピークの時 期が早くなるだけでなく，一度6月19日にピーク

$(57.1 \mu \mathrm{g} / \mathrm{L})$ を示した後, $\mathrm{PO}_{4}-\mathrm{P} の$ 枯渇による濃度 低下を示した後，7月8日に発生した洪水による栄養 塩の補給後に再びピークを迎えており，植物プラン クトンの出現パターンも異なっていた.

\section{c） TN・TP分布に与える影響}

貯水池表層における $\mathrm{TN} ・ \mathrm{TP}$ 濃度には，Chl.aの ように大きなケース間の違いは見られなかった。計 算に用いた河川流入量と $\mathrm{TN}$ と $\mathrm{TP}$ 等の濃度は，どの ケースにおいても同じであるため，流入河川の貫入 位置の違いによる栄養塩の供給水深の違いや藻類の 成長と死滅による変化が，ケース間の $\mathrm{TN} ・ \mathrm{TP}$ 変 化に影響を与えていると考えられる。

\section{5.おわりに}

本研究は，浦山ダムを対象に，JRA25をもとに WRFを用いた力学的ダウンスケーリングを行い, その結果を複数の方法で補正したデータについて精 度を評価するとともに, 貯水池生態系モデルを適応 したときの，バイアス補正が貯水池水質に与える影 響を評価した。ここで，得られた成果をまとめる。

1) 浦山ダム付近の気象データのバイアス補正につ いての検討を行った結果，将来時への適応を考慮 した場合, 頻度分布マッピングが最も適切な補正 方法と考えられた。また, 補正後の精度から, 気 温, 気圧, 日射量, 雲量, 湿度についてはバイア ス補正が可能であるが，風向については統計的ダ ウンスケーリングが有効であり，風速については さらに詳細なダウンスケーリングなどの対応が必 要である。

2) 湖沼生態系水質予測モデルELCOM-CAEDYMを 用いた検討を行った結果，ダウンスケーリングか ら得られた気温や日射量に適切なバイアス補正を 行うことにより，植物プランクトンのバイオマス に大きな影響を与える表層水温に重要な熱収支の 問題を少なくすることができることが分かった.
今後は，ダウンスケーリング手法が流出へ及ぼす 検討を含め，温暖化に伴う詳細なダム貯水池におけ る水量・水質問題を明らかにしていく予定である.

謝辞: 本研究は, 独立行政法人科学技術振興機構, CREST (研究課題「気候変動に適応した調和型都 市圈水利用システムの開発」代表古米弘明)の助成 を受けて行ったものである。また，浦山ダムに関す るデータは，水資源機構荒川ダム総合管理所より提 供いただいた。ここに記して謝意を表する。

\section{参考文献}

1) Wood, A. W. et al. : Long-range experimental hydrologic forecasting for the eastern United States, J. Geophys. Res. Atomos., 107, D20, 4429, 2002.

2) Wood, A. W. et al. : Hydrologic implications of dynamical and statistical approaches to downscaling climate model outputs, Climatic Change, 62, pp.189-216, 2004.

3) Hashino, T. et al. : Evaluation of bias-correction methods for ensemble streamflow volume forecast, Hydrol. Earth Syst. Sci. Discuss., 3, pp.561-594, 2006.

4) 猪股広典, 竹内邦良, 深見和彦: GCM降水量データ の統計的バイアス補正手法に関する一考察, 水工学論 文集，第53巻，pp.223-228, 2009.

5) 渋尾欣弘, 鼎信次郎：大雨に着目した気候モデル日降 水量出力のバイアス補正手法比較, 水工学論文集, 第 54巻, pp.235-240, 2010.

6) Leung, L. R., Hamlet, A. F., Lettenmaier, D. P. and Kumar, A. : Simulations of the ENSO hydroclimate signals in the Pacific Northwest Columbia River basin, Bull. Amer. Meteorol. Soc, 80, pp.2313-2318, 1999.

7) 藤原洋一ら：GCMs・ダウンスケーリング・水文モデ ルに起因する温暖化影響評価の不確実性, 水工学論文 集，第52巻, pp.373-378, 2008.

8) Najafi, M.R. et al. : Assessing the uncertainties of hydrologic model selection in climate change impact studies, Hydrological processes, 25, pp.2814-2826, 2011.

9) Lofgren, B.M. et al. : Evaluation of potential impacts on great lakes water resource based on climate scenarios of two GCMs, J.Great Lakes Res., 28(4), pp.537-554, 2002.

10) Elliott, J.A. et al. : Combining a regional climate model with a phytoplankton community model to predict future changes in phytoplankton in lakes, Freshwater Biology, 50, pp.1404-1411, 2005.

11) Taner, M.U. et al. : Integrated model projections of climate change impacts on a North American lake, Ecological Modelling, 222, 3380-3393, 2011.

12) Fragoso Jr. et al. : Potential effects of climate change and eutrophication on a large subtropical shallow lake, Environmental Modelling \& Software, 26(11), pp.13371348, 2011.

13) 矢島啓, 崔貞圭, Hamilton, D. : 温暖化の季節パターン の変化がダム貯水池の水質に及ぼす影響, 土木学会論 文集B1(水工学), 68 (4), I_1645-I_1650, 2012.

(2012. 9. 30受付) 